\title{
MANAJEMEN PENYULUHAN PARENTING UNTUK MENGURANGI KECANDUAN GADGET ANAK-ANAK USIA SEKOLAH RW 30 CIMINDI HILIR CIMAHI SELATAN
}

\author{
Dewi Sri Mulyati ${ }^{1}$,Sri Nurhayati ${ }^{2}$ \\ 1, 2 Program Studi Pendidikan Masyarakat IKIP Siliwangi, Cimahi, Jawa Barat, Indonesia \\ ${ }^{1}$ haykaldewi1987@gmail.com, ${ }^{2}$ shrie33@yahoo.com
}

Received: Juli, 2020; Accepted: September, 2020

\begin{abstract}
The aim of this research is to find out how parenting program management can reduce the impact of children's gadget addiction in RW 30 Cimindi Hilir. The number of children playing gadgets in RW 30 is because of the free Wi-fi facilities. This study used a descriptive method with a qualitative approach, namely through interview and observation techniques. The respondents in this study were the organizers of the extension program, amounting to 2 people as the main informants and the parents of 12 children as additional informants in RW 30 Cimindi Hilir, Cimahi Selatan Village. The results of this study are summarized as follows: (1) The planning of parenting extension programs is well organized according to the problems at hand, 2) In the implementation of the extension, data is obtained that parents have not received any systematic direction or reference at all. 3) With parenting programs, the level of parents' knowledge about gadgets increases, so they have a way / pattern to divert their children from playing gadgets every day.
\end{abstract}

Keywords: Gadgets, Addiction, Parenting

\begin{abstract}
Abstrak
Tujuan penelitian adalah untuk mengetahui bagaimana manajemen program parenting dapat mengurangi dampak kecanduan gadget anak-anak di lingkungan RW 30 Cimindi Hilir. Banyaknya anak-anak yang bermain gadget di lingkungan RW 30 karena adanya sarana Wi-fi yang dapat diakses secara gratis. Penelitian ini menggunakan metode deskriptif dengan pendekatan kualitatif, yaitu dengan teknik wawancara dan observasi. Adapun responden dalam penelitian ini adalah penyelenggara program penyuluhan yang berjumlah 2 orang sebagai informan utama dan orang tua anak-anak berjumlah 12 orang sebagai informan tambahan di lingkungan RW 30 Cimindi Hilir Kelurahan Cimahi Selatan. Hasil dari penelitian ini disimpulkan sebagai berikut: (1) Perencaan program penyuluhan parenting tertata dengan baik sesuai masalah yang dihadapi, 2) Pada pelaksaan penyuluhan diperoleh data bahwa para orang tua belum sama sekali mendapat arahan atau acuan secara sistematis. 3) Dengan program parenting tingkat pengetahuan orang tua terhadap gadget meningkat, sehingga mereka memiliki cara/ pola untuk mengalihkan anak-anak mereka dari bermain gadget setiap hari.
\end{abstract}

Kata Kunci : Pemberdayaan Masyarakat, Home Industri, Kewirausahaan

How to Cite: Mulyati \& Nurhayati. (2020). Manajemen Penyuluhan Parenting Untuk Mengurangi Kecanduan Gadget Anak-Anak Usia Sekolah Rw 30 Cimindi Hilir Cimahi Selatan. Comm-Edu (Community Education Journal) 3 (3), 253-260.

\section{PENDAHULUAN}

Perkembangan internet saat ini semakin pesat dan menarik pengguna dari berbagai kalangan masyarakat. Walaupun hadirnya internet di Indonesia bisa dikatakan terlambat, namum perkembangannya bisa dikatakan sangat cepat. Berdasarkan data dari situs Internet World Stats, pengguna internet di Indonesia mencapai angka 80 juta orang pada pertengahan tahun 2018. Jauh melebihi data yang diambil pada tahun 2000, dimana jumlah pengguna internet di Indonesia hanya 2 juta orang. 
Game online melalui gadget merupakan permainan (games) yang dapat diakses oleh banyak pemain, dimana mesin-mesin yang digunakan pemain dihubungkan oleh suatu jaringan. Umumnya jaringan yang digunakan untuk bermain adalah internet. Kalangan anak merupakan pangsa pasar gadget yang berjumlah cukup besar. Jumlah pemain game juga cukup besar, tercatat lebih dari 19,8 juta pengguna internet memanfaatkan layanan game online melalui gadget yang tersedia di Indonesia. Sebanyak 70\% pemain gadget di Indonesia berusia 13-17 tahun dan 18-24 tahun.

Gadget juga membawa dampak yang besar terutama pada perkembangan anak maupun jiwa seseorang. Yang mendominasi memainkan gadget adalah kalangan pelajar, mulai dari SD, SMP, dan SMA. Pelajar yang sering memainkan suatu gadget, akan menyebabkan ia menjadi ketagihan atau kecanduan. Ketagihan memainkan gadget akan berdampak buruk, terutama dari segi akademik dan sosialnya. Walaupun kita dapat bersosialisasi dengan gadget dan pemain lainnya, gadget juga kerap membuat pemainnya melupakan kehidupan sosial dalam kehidupan sebenarnya.

\section{LANDASAN TEORI}

Penyuluhan adalah turunan dari kata exstension yang dipakai secara luas dan umum dalam bahasa Indonesia. Penyuluhan berasal dari kata dasar suluh yang berarti pemberi terang di tengah kegelapan. Dalam bahasa Belanda penyuluhan disebut voorlichting yang berarti memberi penerangan untuk menolong seseorang menemukan jalanya, dalam bahasa inggris dan jerman mengistilahkan penyuluhan sebagai pemberian saran atau Beratung yang berarti seseorang dapat memberikan petunjuk bagi seseorang tetapi seseorang tersebut yang berhak untuk menentukan pilihannya.

Secara bahasa parenting berasal dari bahasa inggris, dari kata parent yang artinya orang tua. Sedangkan dalam kamus Oxford, parenting adalah the proces of caring your child or childrn. Takdir Ilahi, dalam buku "Quantum Parenting" ia memaknai proses mmanfaatkan peran asuh orang tua dalam tumbuh kembang anak.

Hakekat parenting adalah pola pengasuhan yang melibatkan unsur-unsur keluarga dan masyarakat dalam mendidik dan mengembangkan karakter dan jati diri anak-anak dalam mempersiapakan mereka menyongsong masa depan mereka sebagai manusia seutuhnya. Ratna Megawangi (2007) menjelaskan bahwa parenting itu merujuk pada suasana kegiatan belajar mengajar yang menekankan kehangatan bukan ke arah suatu pendidikan satu arah atau tanpa emosi.

\section{Macam-macam Pola Asuh Orang Tua}

Menurut Baumrind (dikutip oleh Wawan Junaidi,2010), terdapat 4 macam pola asuh orang tua:

\section{a. Pola Asuh Demokratis}

Pola asuh demokratis adalah pola asuh yang memprioritaskan kepentingan anak, akan tetapi tidak ragu-ragu mengendalikan mereka. Orang tua dengan pola asuh ini bersikap rasional, selalu mendasari tindakannya pada rasio atau pemikiran-pemikiran. Orang tua tipe ini juga bersikap realistis terhadap kemampuan anak, tidak berharap yang berlebihan yang melampaui kemampuan anak. Orang tua tipe ini juga memberikan kebebasan kepada anak untuk memilih dan melakukan suatu tindakan, dan pendekatannya kepada anak bersifat hangat.

b. Pola Asuh Otoriter

Pola asuh ini cenderung menetapkan standar yang mutlak harus dituruti, biasanya dibarengi dengan ancaman-ancaman. Orang tua tipe ini cenderung memaksa, memerintah, menghukum. 
Apabila anak tidak mau melakukan apa yang dikatakan oleh orang tua, maka orang tua tipe ini tidak segan menghukum anak. Orang tua tipe ini juga tidak mengenal kompromi dan dalam komunikasi biasanya bersifat satu arah. Orang tua tipe ini tidak memerlukan umpan balik dari anaknya untuk mengerti mengenai anaknya.

c. Pola Asuh Permisif

Pola asuh ini memberikan pengawasan yang sangat longgar. Memberikan kesempatan pada anaknya untuk melakukan sesuatu tanpa pengawasan yang cukup darinya. Mereka cenderung tidak menegur atau memperingatkan anak apabila anak sedang dalam bahaya, dan sangat sedikit bimbingan yang diberikan oleh mereka. Namun orang tua tipe ini biasanya bersifat hangat, sehingga seringkali disukai oleh anak.

d. Pola Asuh Penelantar

Orang tua tipe ini pada umumnya memberikan waktu dan biaya yang sangat minim pada anakanaknya. Waktu mereka banyak digunakan untuk keperluan pribadi mereka, seperti bekerja, dan juga kadangkala biaya pun dihemat-hemat untuk anak mereka. Termasuk dalam tipe ini adalah perilaku penelantar secara fisik dan psikis pada ibu yang depresi. Ibu yang depresi pada umumnya tidak mampu memberikan perhatian fisik maupun psikis pada anak-anaknya.

Definsi dari gadget sendiri adalah suatu alat atau perangkat yang dirancang dengan teknologi canggih dengan fungsi yang lebih spesifik serta bersifat praktis atau memudahkan bagi para pengguna-penggunanya. Salah satu gadget yang keberadaanya paling penting dan semakin berkmbang dari dulu hingga saat ini adalah handphone atau yang biasa dikenal dengan smarthphone. Pada awalnya handphone hanya digunakan sebagai alat komunikasi jarak jauh tanpa perantara namun dengan berbagai macam pengembangan suatu smartphone juga dapat digunakan untuk komponen internet, mendengarkan audio, video, game, sebagai komponen media sosial, untuk memfoto dan masih banyak lagi. Hal ini juga merupakan wujud dari peran vital gadget bagi masyarakat luas.

\section{Dampak Bermain Gadget}

Dampak dan pengaruh dari bermain gadget sendiri memiliki arti dan pemahaman yang luas. Banyak para ahli yang mengemukakan pendapatnya tentang bahaya kecanduan bermain gadget. "Secara tidak sadar, saat ini anak-anak sudah mengalami ketergantungan menggunakan gadget. Ketergantungan inilah yang menjadi salah satu dampak negatif yang sangat berpengaruh." (Prasetyo, 2013).

\section{METODE}

Penelitian ini menggunakan metode deskriptif kualitatif. Menurut Iskandar (2013:62) bahwa penelitian deskriptif merupakan penelitian untuk memberikan uraian mengenai fenomena atau gejala sosial yang diteliti dengan mendeskripsikan tentang nilai variabel mandiri, baik satu variabel atau lebih (independent) berdasarkan indikator-indikator dari variabel yang diteliti tanpa membuat perbandingan atau menghubungkan antar variabel yang diteliti untuk eksplorasi dan klasifikasi dengan variabel yang diteliti. Pendekatan yang dilakukan adalah penelitian kualitatif, karena penelitian ini bertujuan untuk menggambarkan keadaan atau fenomena yang terjadi.

Menurut Sugiyono (2014:8) menjelaskan bahwa metode penelitian kualitatif sering disebut metode penelitian naturalistic karena penelitianya dilakukan pada kondisi alamiah (natural setting); disebut juga sebagai metode etnographi, karena pada awalnya metode ini lebih banyak digunakan untuk penelitian bidang antropogi budaya; disebut sebagai metode kualitatif, karena data yang terkumpul dan analisisnya lebih bersifat kualitatif. Pendekatan ini juga berdasarkan 
pertimbangan bahwa data yang menggambarkan proses perencanaan pengorganisasian, pelaksanaan dan pengevaluasian. Menurut Darmadi (2014:1) metode penelitian merupakan pendekatan atau cara yang dilakukan untuk mendapatkan data dengan tujuan tertentu. pada penelitian ini, peneliti mengambil responden penelitian yaitu penyelenggara penyuluhan yang kemudian disebut informan utama dan peserta penyuluhan selanjutnya disebut informan tambahan.

Adapun jumlah responden informan utama berjumlah 2 orang dan informan tambahan berjumlah 12 orang. Pendekatan yang dilakukan menggunakan metode deskriptif kualitatif. Pendekatan ini memberikan gambaran tentang kondisi dan keadaan secara alami.

\section{HASIL DAN PEMBAHASAN}

Cimahi Selatan adalah salah satu Kelurahan yang merupakan bagian dari Kecamatan Cibeurueum Kabupaten Bandung Barat. Merupakan bagian dari Kota Cimahi bagian Selatan. Sejarah terbentuknya kota ini bisa dikatakan memiliki sejarah yang panjang. Kalaupun di ulas secara mendetail tidak akan tergambar dalam waktu yang singkat. Peneliti memfokuskan topik wilayah penelitian skripsi ini pada salah satu Rukun Warga yang ada di Kelurahan Cimahi Selatan, yaitu RW 30 Cimindi Hilir. Menurut data statistik tahun 2018, jumlah penduduk yang ada di lingkungan RW 30 Cimindi Hilir adalah kurang lebih 1243 jiwa. Terdiri dari $678 \mathrm{KK}$ Adapun sarana dan prasarana yang ada di RW 30 Kelurahan Cimahi Selatan dapat di deskripsikan sebagai berikut :

- Gedung serba guna

- Masjid Al-Ikhlas

- Lapangan Bulutangkis

- Poskamling

- Koneksi internet ( $\mathrm{Wi}-\mathrm{Fi})$

- Jumlah penduduk

\section{Perencanaan Program Penyuluhan}

Pada tahap kegiatan penelitian yang akan dilakukan di RW 30 ini, peneliti mencari dan mengumpulkan data dari narasumber penyelenggara program penyuluhan berupa kerangka rancangan kegiatan yang akan dilakukan. Tahapan perencaanan yang didapat meliputi:

a. Menyiapkan Materi Dasar Penyuluhan Parenting

Pada kegiatan penyiapan materi ini, narasumber mengambil materi yang bersifat sederhana dan objektif sehingga akan lebih mudah dipahami oleh para peserta penyuluhan itu sendiri. karena pada umumnya para peserta penyuluhan ini adalah orang tua yang sudah memasuki usia lanjut. Adapun rincian materi yang akan di sampaikan adalah:

1) Defini parenting

2) Pengertian gadget

3) Standar bermain gadget untuk tiap segmen usia

4) Teknik menerapkan pola asuh anak

b. Mengumpulkan Daftar Peserta Penyuluhan

Daftar peserta penyuluhan terdiri dari para orang tua anak-anak di lingkungan RW 30 Cimindi Hilir Kelurahan Cimahi Selatan sebanyak 12 orang peserta, yaitu:

1) Abduk Rozak

2) Sugiyanto

3) Wiwin 

4) Dadan Irmawan
5) Solehudin
6) Wartini
7) Enok Sumiyati
8) Ridwan
9) Wawan Maulana
10) Cucu Herawati
11) Oyo Suharto
12) Kirman

c. Membuat Materi Susunan Acara

Kegiatan penyuluhan ini memiliki susunan acara sebagai berikut:

1) Pembukaan acara

2) Sambutan-sambutan ketua pelaksana dan pemerintahan setempat

3) Penyampaian materi

4) Break/ istirhat

5) Penyampaian materi

6) Penutup

d. Menyiapkan Anggaran Dasar Sarana dan Prasarana Penyuluhan

Anggaran dan prasarana yang dipakai merupakan kerjasama penyelenggara dengan pemerintahan setempat. yaitu menggunakan dana donatur serta memakai gedung serbaguna RW 30.

\section{Pelaksaan Kegiatan Penyuluhan}

Dalam tahap ini, proses pelaksanaan kegiatan penyuluhan meliputi penyampaian materi yang telah disusun. Pelaksanaan kegiatan penyuluhan ini, menitikberatkan kepada para orang tua agar memahami metode dan teknik parenting yang benar sehingga dapat diterapkan dalam keluarganya, terutama mampu menurunkan kecanduan anaknya dalam hal bermain gadget. Selain itu juga para peserta diberi kesempatan untuk tanya jawab seputar permasalahan yang mereka hadapi. Mereka dibekali dengan modul yang dapat di baca pada saat pelatihan dan juga video pola memberikan asuhan, arahan dan teguran yang sesuai dengan tingkatan usia anakanak. sehingga peserta dapat dengan mudah menerapkanya dalam kehidupan sehari-hari. Adapun pelaksanaan penyuluhannya terdiri dari:

a. Penyampaian materi parenting dalam pola asuh anak

Pada tahap penyampaian materi tentang pola asuh, para peserta penyuluhan di berikan pengetahuan tentang tata cara dan teknik mengasuh dan memberikan ajaran serta memberikan contoh kepada anak-anaknya. sehingga kelak peserta dapat menjadi suri tauladan untuk anak-anaknya.

b. Penyampaian materi tentang gadget secara umum

Gadget adalah sebuah istilah yang berasal dari bahasa Inggris, yang artinya perangkat elektronik kecil yang memiliki fungsi khusus. Dalam bahasa Indonesia, gadget disebut sebagai "acang". Salah satu hal yang membedakan gadget dengan perangkat elektronik lainnya adalah unsur "kebaruan". Artinya, dari hari ke hari gadget selalu muncul dengan menyajikan teknologi terbaru yang membuat hidup manusia menjadi lebih praktis. Gadget adalah piranti yang berkaitan dengan perkembangan teknologi masa kini. Yang termasuk gadget misalnya tablet, smartphone, notebook, dan sebagainya.

Gadget memang memiliki dampak positif bagi pola pikir anak yaitu membantu anak dalam mengatur kecepatan bermainnya, mengolah strategi dalam permainan, dan membantu 
meningkatkan kemampuan otak kanan anak. Tetapi dibalik kelebihan tersebut juga dapat berdampak buruk pula bagi daya kembang anak. Berbagai radiasi di dalam gadget yang dapat merusak jaringan syaraf dan otak anak bila anak sering menggunakan gadget. Selain itu, juga dapat menurunkan daya aktif anak dan kemampuan anak untuk berinteraksi dengan orang lain. Anak menjadi kurang interaktif dan lebih suka sendiri dengan zona nyamannya bersama gadget. Sehingga menimbulkan sikap individualis pada anak dan kurangnya sikap peduli terhadap sesama baik terhadap teman, maupun orang lain.

c. Penyampaian materi akan bahaya kecanduan gadget bagi anak-anak.

Dalam materi ini disampaikan pengetahuan tentang gadget serta dampaknya sebagai berikut:

Gadget yang sederhana sampai terumit saat ini sudah tersedia dan sangat mudah ditemukan serta pengaksesannya oleh siapa saja yang ingin menggunakannya. Kehadiran game online tersebut di tengah-tengah kehidupan masyarakat saat ini memberikan dampak berupa yang menguntungkan dan merugikan diantaranya sebagai berikut:

1) Lebih Berkonsentrasi

Game menuntut untuk dapat berkonsentrasi atau lebih fokus karena dalam dunia game menemukan hal baru dan tentunya akan menambah wawasan baru, gamers dapat secara tidak langsung mengkondisikan dirinya untuk mengetahui kadaan sekitar. Sehingga dalam hal ini pengguna atau gamers dapat berkonsentrasi dalam suatu hal yang menurutnya menarik. Bermain game sekitar 20 menit sebelum belajar dapat memancing konsentrasi dalam belajar.

2) Berkembangnya kemampuan

Setiap orang yang sudah mengetahui strategi dalam game dapat meningkatkan daya kemampuan berkembang dalam bidang ilmu Matematika, pemecahan masalah dan kemampuan membaca, terlebih lagi bila game yang biasanya dimainkan menggunakan bahasa Inggris. Selain itu juga dapat menamba wawasan mengenai kosa kata yang dimiliki sebelumnya dan perkembangan zaman.

3) Mengalihkan perhatian

Mengalihkan perhatian misalnya, apabila seorang anak atau anak yang sedang menjalani perawatan yang cukup serius seperti kemoterapi dapat mengalihkan rasa sakit dengan cara memberikan waktu untuk bermain game disaat seperti itu akan memberikan kemudahan kepada perawat dalam memberikan obat. Dampak positif lainnya dari game online adalah:

- Otak gamer akan lebih aktif dalam berfikir.

- Reflek berpikir dari gamer akan lebih cepat merespon.

- Emosional gamer dapat diluapkan dengan bermain game.

d. Diskusi dan tanya jawab

Pada sesi diskusi peserta penyuluhan menyamapaikan dan membrikan pertanyaan dan halhal yang belum mereka pahami secara lebih. Diskusi bersifat terbuka dan umum, sehingga peserta bebas menyampaikan masalah dan keluh kesah yang mereka miliki selama menjadi orang tua.

e. Games dan doorprice 
Setelah peserta mengikuti rangkaian kegiatan penyuluhan ini, peserta mulai memahami dan lebih jauh dapat mencegah dan bahkan mengobati kebiasaan/kecanduan anaknya dalam bermain gadget setiap hari. Di samping itu juga, menguatkan peran peserta sebagai orang tua dalam menjadi pilar yang kokoh dalam mendidik keluarganya.

\section{Evaluasi Pelaksaan Kegiatan Penyuluhan}

Pada tahap evaluasi kegiatan, dilakukan seminggu setelah program penyuluhan dilakukan. Dari hasil wawancara terhadap para peserta yang telah mengikuti penyuluhan, mereka mengakui dapat mengontrol dan mengendalikan kegiatan dan keseharian anak-anak mereka dalam hal membatasi keinginan bermain gadget. Mereka dapat menerapkan metode pola asuh yang sesuai dengan sifat dan karakter dari anak-anak mereka sehingga bisa mengarahkan kegiatan anakanaknya lebih ke hal yang bersifat positif dan bermanfaat. Hasil evaluasi terhadap para peserta penyuluhan dapat dijabarkan sebagai berikut:

a. Sebelum kegiatan penyuluhan:

- Sebelum dilakukan kegiatan penyuluhan parenting, para peserta tidak memahami arti dari parenting.

- Peserta tidak mengetahui jenis dan fungsi dari gadget secara umum.

- Sebelum penyuluhan, para peserta tidak memahami standar dan ketentuan bermain gadget terhadap anak-anaknya.

- Para peserta tidak memahami metode pola asuh yang baik.

- Para peserta tidak mengetahui bahaya dari bermain gadget setiap hari.

b. Setelah dilakukan kegiatan penyuluhan:

- Peserta penyuluhan dapat memahami dan mengetahui definisi dari parenting secara luas.

- peserta penyuluhan memiliki pengetahuan tentang jenis dan fungsi gadget.

- Peserta penyuluhan mampu menerapkan pola asuh yang baik dan benar terhadap anakanaknya.

- Para peserta mendapat pengetahuan tentang standar dan ketentuan yang benar tentang penggunaan gadget.

- Peserta penyuluhan mengetahui bahaya dan dampak dari kecanduan bermain gadget pada anak-anak mereka, sehingga mereka lebih mengawasi dan mengurangi frekuensi anak-anak mereka dalam bermain gadget.

Hasil evaluasi ini sangat penting dilakukan untuk menjadi acuan dan dasar terhadap kegiatankegiatan penyuluhan selanjutnya, sehingga apabila ada kegiatan serupa yang akan dilakukan dapat menjadi lebih baik dan efektif hasilnya.

\section{KESIMPULAN}

Dari hasil dan pembahasan yang dilakukan, melalui data yang telah dikumpulkan dan dijabarkan sebelumnya maka dapat dijadikan dasar untuk menarik beberapa kesimpulan sebagai berikut:

1. Penyuluhan parenting yang dilakukan di RW 30 Cimindi Hilir dapat mengurangi dampak kecanduan gadget pada anak-anak usia sekolah.

2. Melalui manajemen parenting orang tua dari anak-anak mempunyai pemahaman dan pengetahuan tentang standar bermain gadget bagi anak-anak mereka. 
3. Manajemen penyuluhan parenting memberikan gambaran secara umum kepada khalayak tentang dampak dan efek negatif dari keseringan bermain gadget

4. Melalui manajemen parenting dapat dibuat perencaan dan penyusunan dalam melaksanakan program tersebut.

Melalui optimalisasi program penyuluhan yang telah dilaksanakan tersebut, para peserta sebagai orang tua akan memiliki peran yang lebih maksimal dan terarah sehingga mampu mengandalikan dan mengawasi serta menciptakan keluarga yang berakhlak dan berbudi pekerti yang luhur.mJadi secara garis besar penelitian ini memberikan pemahaman jika manajemen parenting ini dilakukan dengan metode yang benar dapat mengurangi dampak kecanduan anak-anak dalam bermain gadget.

\section{DAFTAR PUSTAKA}

Chabib Soleh. Dialektika Pembangunan dengan Pemberdayaan, Bandung: Fokusmedia

Horton dan Hurt,(1987 : 59) lihat dalam Damsar, dan Indrayani, Pengantar Sosiologi Ekonomi (Jakarta : Kencana, 2009) hal 5

Kartasasmita, Ginanjar. 1995 Ekonomi Rakyat : Memadukan Pertumbuhan dan Pemerataan : Jakarta : CIDES, 1995

Kindervatter, S. (1979). Nonformal Education As An Empowering With Studies From

Lexy J Moleong, Metode Penelitian Kualitatif, Bandung : Remaja Rosda Karya, 2002

Milles, Mathes B dan Huberman, Michael 1992. Analisis Data Kualitatif terjemahan, Tjetjep Rohendi Rohidi. Jakarta :UI Press

Moeloeng, Lexy J 2002 Metodologi Penelitian Kualitatif Bandung : Sinar Baru Algesindo

Prof. Dr. Hamid Darmadi, M Pd. Metode Penelitian Pendidikan dan Sosial, Bandung : Alfabeta

Prof. H. D. Sudjana S. Pendidikan Nonformal ( Nonformal Education), Bandung : Falah Production 2010

Riyanto, Astim dan Arifah.(2013). Kapita Selekta Kewirausahaan. Bandung : Yapemdo

Robert Bogdan dan Steve Tylor. 1992 Pengantar Metode Penelitian Kualitatif Suatu Fenomenologis Terhadap Ilmu-ilmu Sosial terjemahan Ali Furhan. Surabaya : Usaha Nasional

Suharsimi. Arikunto, Prosedur Penelitian Suatu Pendekatan Praktek, Jakarta : Rineka Cipta, 1996

Suhendra, 2006 Peranan Birokrasi dalam Pemberdayaan Masyarakat. Bandung : Alfabeta

Tohar, M (2000), Industri Kecil. Bandung, Remaja Rosda Karya.

Yunus, M (2004). Menciptakan Dunia Tanpa Kemiskinan : Bagaimana Bisnis Sosial Mengubah Kehidupan Kita. Jakarta : Gramedia Pustaka Utama 